\title{
Treatment of severe primary IGF-1 deficiency using rhIGF-1 preparation - first three years of Polish experience
}

\author{
Leczenie ciężkiego pierwotnego niedoboru IGF-1 z zastosowaniem preparatu \\ rhIGF-1 — pierwsze trzy lata doświadczeń w Polsce
}

\begin{abstract}
Elżbieta Petriczko ${ }^{1}$, Tomasz Jackowski ${ }^{1}$, Anita Horodnicka-Józwa', Beata Wikiera ${ }^{2}$, Anna Noczyńska², Maria Korpal-Szczyrska ${ }^{3}$, Dorota Birkholz-Walerzak ${ }^{3}$, Ewa Małecka-Tendera', Barbara Kalina-Faska ${ }^{4}$, Maria Kalina ${ }^{5}$, Ewa Barg6, Iwona Beń-Skowronek ${ }^{7}$, Leszek Szewczyk, Maciej Hilczer ${ }^{8,}{ }^{7}$, Joanna Smyczyńska ${ }^{8}$, Renata Stawerska ${ }^{8}$, Andrzej Lewiński ${ }^{8,}{ }^{10}$, Katarzyna Ziora ${ }^{11}$, Artur Bossowski ${ }^{12}$, Edyta Pietrewicz ${ }^{12}$, Beata Pyrżak ${ }^{13}$, Andrzej Kędzia ${ }^{14}$, Mieczysław Szalecki15,16, Agnieszka Kilian ${ }^{1}$, Mieczysław Walczak ${ }^{1}$
\end{abstract}

\author{
${ }^{1}$ Department of Paediatrics, Endocrinology, Diabetology, Metabolic Disorders, and Cardiology of Developmental Age, Pomeranian \\ Medical University, Szczecin, Poland \\ ${ }^{2}$ Department of Endocrinology and Diabetology of Children and Adolescents, Wroclaw Medical University, Wroclaw, Poland \\ ${ }^{3}$ Department of Paediatrics, Diabetology, and Endocrinology, Medical University of Gdansk, Gdansk, Poland \\ ${ }^{4}$ Department of Paediatrics, Endocrinology, and Diabetes, Medical University of Silesia, Katowice, Poland \\ ${ }^{5}$ Division of Clinical Genetics, Department of Molecular Biology and Genetics, School of Medicine in Katowice, Medical University \\ of Silesia, Katowice, Poland \\ ${ }^{6}$ Department of Basic Medical Sciences, Wroclaw Medical University, Wroclaw, Poland \\ ${ }^{7}$ Department of Paediatric Endocrinology and Diabetology, Medical University Children's Hospital, Lublin, Poland \\ ${ }^{8}$ Department of Endocrinology and Metabolic Diseases, Polish Mother's Memorial Hospital — Research Institute, Lodz, Poland \\ ${ }^{9}$ Department of Paediatric Endocrinology, Medical University of Lodz, Lodz, Poland \\ ${ }^{10}$ Department of Endocrinology and Metabolic Diseases, Medical University of Lodz, Lodz, Poland \\ ${ }^{11}$ Department of Paediatrics, Medical University of Silesia, Katowice, Poland \\ ${ }^{12}$ Department of Paediatrics, Endocrinology, and Diabetology with Cardiology Division, Medical University of Bialystok, Bialystok, Poland \\ ${ }^{13}$ Department of Paediatrics and Endocrinology, Medical University of Warsaw, Warsaw, Poland \\ ${ }^{14}$ Department of Clinical Auxology and Paediatric Nursing, Poznan University of Medical Sciences, Poznan, Poland \\ ${ }^{15}$ Department of Endocrinology and Diabetology, Children's Memorial Health Institute, Warsaw, Poland \\ ${ }^{16}$ The Faculty of Medicine and Health Sciences, Jan Kochanowski University, Kielce, Poland
}

\begin{abstract}
Introduction: The objective of this study was to analyse the effects of the first three years of treatment with recombinant human insulinlike growth factor 1 (rhIGF-1) in patients from the Polish population.

Material and methods: Twenty-seven children ( 22 boys and five girls) aged 2.8 to 16.0 years old were qualified for treatment with rhIGF-1 (mecasermin) in different treatment centres, according to Polish criteria: body height below -3.0 SD and IGF-1 concentration below percentile 2.5 with normal growth hormone (GH) levels. Mecasermin initial dose was $40 \mu \mathrm{g} / \mathrm{kg}$ bw twice a day and was subsequently increased to an average of $100 \mu \mathrm{g} / \mathrm{kg} \mathrm{bw}$ twice a day. Body height, height velocity, weight, body mass index (BMI), and adverse events were measured. Results: Mecasermin treatment resulted in a statistically significant increase in body height $(1.45 \pm 1.06 \mathrm{SD} ; \mathrm{p}<0.01)$ and height velocity in comparison with pre-treatment values. The biggest change in height velocity happened during the first year and diminished during subsequent years. Body weight and BMI also increased significantly after treatment $(1.16 \pm 0.76 \mathrm{SD}$ and $0.86 \pm 0.75 \mathrm{SD}$, respectively; $\mathrm{p}<0.01)$. Eight patients reported adverse events. These were mild and temporary and did not require treatment modification except in two patients.

Conclusions: Treatment with rhIGF-1 was effective and safe in Polish patients with primary IGF-1 deficiency. It had a clear beneficial effect on the height of the patients and significantly accelerated the height velocity, particularly in the first year of treatment. (Endokrynol Pol 2019; 70 (1): 20-27)
\end{abstract}

Key words: insulin-like growth factor-1 (IGF-1); growth hormone insensitivity; IGF-1 deficiency; short stature; growth-promoting therapy; mecasermin; Poland

\section{Streszczenie}

Wstęp: Celem badania była analiza efektów pierwszych 3 lat leczenia preparatem rekombinowanego ludzkiego insulinopodobnego czynnika wzrostu 1 (rhIGF-1) u pacjentów w populacji polskiej.

Materiał i metody: Do leczenia rhIGF-1 (mekaserminą) zakwalifikowano w różnych ośrodkach 27 dzieci (22 chłopców i 5 dziewcząt) w wieku 2,8-16,0 lat, zgodnie z polskimi kryteriami: wysokość ciała $<-3,0$ SD oraz stężenie IGF-1 < 2,5 centyla przy prawidłowym 
stężeniu hormonu wzrostu (GH). Początkowa dawka mekaserminy wynosiła $40 \mu \mathrm{g} / \mathrm{kg}$ masy ciała (mc.) i była stopniowo zwiększana do średnio $100 \mu \mathrm{g} / \mathrm{kg}$ mc. 2 razy dziennie. Oceniano wysokość ciała, tempo wzrastania, masę ciała, wartość wskaźnika masy ciała (BMI) oraz zdarzenia niepożądane.

Wyniki: Leczenie mekaserminą skutkowało statystycznie istotnym przyrostem wysokości ciała $(1,45 \pm 1,06 \mathrm{SD}$; p $<0,01)$ oraz tempa wzrastania w porównaniu z wartościami sprzed leczenia. Najwyższe tempo wzrastania zaobserwowano w pierwszym roku leczenia, zmniejszało się ono w latach kolejnych. Przyrosty masy ciała i BMI w trakcie leczenia również osiągały wartości istotne statystycznie (odpowiednio 1,16 \pm 0,76 SD and 0,86 \pm 0,75 SD; p < 0,01). Zgłoszono wystąpienie 8 zdarzeń niepożądanych. Poza dwójką dzieci zdarzenia te były łagodne i przemijające, nie wymagały modyfikacji leczenia.

Wnioski: W populacji polskich dzieci z pierwotnym niedoborem IGF-1 leczenie z zastosowaniem rhIGF-1 było skuteczne i bezpieczne. Wykazano korzystny wpływ na wysokość ciała i znaczący wzrost tempa wzrastania, szczególnie w pierwszym roku leczenia. (Endokrynol Pol 2019; 70 (1): 21-27)

Słowa kluczowe: insulinopodobny czynnik wzrostu 1 (IGF-1); oporność na hormon wzrostu; niedobór IGF-1; niedobór wzrostu; terapia promująca wzrastanie; mekasermina; Polska

\section{Introduction}

Primary deficiency of insulin-like growth factor-1 (IGF-1) is a rare cause of short stature caused by impaired functioning of the growth hormone $(\mathrm{GH})$ - IGF-1 axis. Patients suffering from the disease have low levels of IGF-1 despite normal or even elevated levels of GH. The most striking form of IGF-1 deficiency is Laron syndrome, in which there is a receptor resistance to GH leading to IGF-1 secretion disorders.

IGF-1 was discovered as a hormone in the 1950s. It is a hormone with a peptide structure, similar to that of insulin, which consists of chains A and B, connected with peptide C. IGF-1 is produced mainly in the liver, but also in other tissues through a paracrine/autocrine mechanism. Its production is stimulated by GH. In the circulation, IGF-1 occurs mainly (> 99\%) in the form bound to specific IGF binding proteins (IGFBPs) and their acid-labile subunit (ALS). It is an essential growth factor in the human body. The site of IGF-1 action is its specific receptor, IGF1R, which is a tyrosine kinase receptor that activates further intracellular transduction mediated by protein kinase B. IGF-1 influences the growth of most of the tissues in the body, especially skeletal, muscle, and cartilage. A $40 \%$ increase in $\mathrm{GH}-$ dependent growth results from the action of GH on maturing bones and the para/autocrine action of IGF-1. Thus, IGF-1 deficiency is related to the lower final height of the patient. Due to the mechanism of factor secretion, recombinant human $\mathrm{GH}(\mathrm{rhGH})$ therapy is not effective in patients with short stature caused by primary IGF-1 deficiency [1,2].

Despite the discovery of IGF-1 in the 1950s, the description of its molecular structure was possible only in 1978. The 1980s brought about the development of a recombinant human IGF-1 (rhIGF-1) obtained by microbiological methods and the beginning of research on its effects and effectiveness in therapy [3].

The first preparation of rhIGF-1 (mecasermin, trade name Increlex) was registered for the treatment of short-statured patients in 2005 in the USA, and in 2007 in Europe. In Poland, treatment of patients with severe primary IGF-1 deficiency with rhIGF-1 has been covered by a therapeutic program since 2009 . The first results of treatment were described in a previous publication [4].

The authors of the present article discuss the therapeutic effects observed in the first three years of treatment with rhIGF-1 in patients from the Polish population.

\section{Material and methods}

All patients were qualified for treatment based on unified criteria for all treatment centres. Patients were diagnosed with severe primary IGF-1 deficiency according to Polish criteria if they presented extremely short-stature, defined as body height below $-3.0 \mathrm{SD}$ for sex and age, and IGF-1 concentration below percentile 2.5 for sex and age with normal GH levels (confirmed in the nocturnal surge and/or stimulation tests). The IGF-1 generation test was carried out in all patients to assess the insensitivity to GH. According to the standard most commonly used in Poland, the test was carried out for four days. The initial concentration of IGF-1 was assessed, and then at 18:00 the growth hormone was administered subcutaneously for four consecutive days in a daily dose of $0.033 \mathrm{mg} / \mathrm{kg}$ bw. Subsequently, the concentration of IGF-1 was assessed in the morning. An increase of IGF-1 concentration of less than 15 $\mathrm{ng} / \mathrm{ml}$ indicated complete (severe) IGF-1 deficiency, a change ranging between $15-160 \mathrm{ng} / \mathrm{ml}$ suggested a partial IGF-1 deficiency, while a change greater than $160 \mathrm{ng} / \mathrm{ml}$ excluded primary IGF-1 deficiency. Figure 1 illustrates the technique for conducting the test.

The group of Polish patients described in this study are the first 27 children treated with rhIGF-1 in Poland and include 22 boys $(81.48 \%)$ and five girls $(18.52 \%)$. The average age at the start of treatment was 10.06 years (9.56 for boys, and 12.27 for girls); the youngest patient was 2.8 years old, and the oldest was 16.2 years old.

The average children's body height expressed as SDS in relation to age and sex was $-3.52 \mathrm{SD}$. The mean baseline concentration of IGF-1 expressed as SDS in 


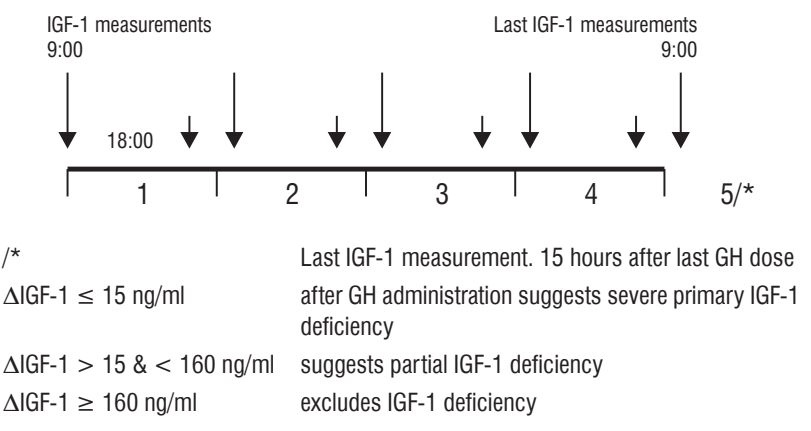

Figure 1. IGF-1 generation test

Rycina 1. Test generacji IGF-1

relation to sex and age was $-2.17 \mathrm{SD}$. Twenty-five of the patients were prepubescent, and two of them were at Tanner's stage II of sexual development. One of the children did not have a body height lower than -3.0 SD for sex and age, and the other one did not have initial IGF-1 below percentile 2.5 for age and sex. One of the children's pre-treatment height velocity was 7.5 $\mathrm{cm} /$ year, despite which, the child still had short stature with body height SDS -3.32. Detailed characteristics of the group are presented in Table I.

All patients started treatment with a relatively low dose of the drug, and it was successively increased during the following months of treatment. The initial dose of mecasermin was $40 \mu \mathrm{g} / \mathrm{kg}$ bw twice a day, which is the minimum dose in the algorithm recommended in Poland. After 12 months, the average dose increased to $80 \mu \mathrm{g} / \mathrm{kg}$ bw (minimum 60, maximum $120 \mu \mathrm{g} / \mathrm{kg} \mathrm{bw}$ ) twice a day to finally reach an average value of 100 (80-120) $\mu \mathrm{g} / \mathrm{kg}$ bw twice a day. The maximum dose of mecasermin used was $120 \mu \mathrm{g} / \mathrm{kg}$ bw twice a day.

The treatment of all children was monitored in the same way in each of the treatment centres. Control visits took place every three months. The concentration of IGF-1, IGFBP-3, and fasting glucose were assessed during

Table I. Group characteristics

Tabela I. Charakterystyka grupy badanej

\begin{tabular}{lccc}
\hline Parameter & Mean & Min & Max \\
\hline Age [years] & 10.06 & 2.80 & 16.20 \\
\hline Body height, SDS & -3.52 & -6.47 & -2.33 \\
\hline Body weight, SDS & -3.14 & -5.77 & -1.19 \\
\hline BMI, SDS & -1.79 & -5.49 & 0.54 \\
\hline IGF-1, SDS & -2.17 & -2.59 & -1.56 \\
\hline Max. GH concentration [ng/ml] & 24.37 & 10.70 & 50.10 \\
\hline Fasting glucose [mg/dl] & 81.28 & 62.00 & 96.00 \\
\hline HbA ${ }_{1 c}$ & $5.31 \%$ & $4.78 \%$ & $5.90 \%$ \\
\hline Height velocity [cm/year] & 4.55 & 0.90 & 7.50 \\
\hline
\end{tabular}

each control visit. Every six months, the concentrations of thyrotropin (TSH), free thyroxine (FT4), and serum electrolytes were evaluated. Additionally, every 12 months an oral glucose tolerance test was carried out, the percentage of glycated haemoglobin was determined, cardiac consultation with echocardiography and laryngological consultation with audiometric examination were carried out, and bone age was assessed. Depending on clinical indications, Polish guidelines recommend performing neuroimaging in patients once a year. Treatment of two of the patients was terminated early due to side effects of the treatment - after 24 and 30 months, respectively. The analysed group reaching the end of the study (36 months of treatment) consisted of 25 children.

For further analyses, the group was later divided in two according to maximal GH concentration and baseline IGF-1 SDS by the median, which was 19.1 $\mathrm{ng} / \mathrm{ml}$ in the case of $\mathrm{GH}$ peak and -2,22 SD in the case of IGF-1 SDS.

\section{Methods of statistical analysis}

Statistical analysis was performed in the Stata 11.0 program. The Shapiro-Wilk test was used to verify the normality of distributions. Since the distribution of most variables deviated from the normal distribution, nonparametric methods were used to test the differences. The Mann-Whitney $U$ test was used to analyse the differences in mean values, and relationships between continuous variables were examined by correlation and regression analysis.

The analysis of categorical variables was carried out with contingency table methods, using Pearson's chi-squared test of independence. Because most variables did not have a normal distribution, the nonparametric Spearman correlation was used to assess the dependence of continuous variables. In multivariate correlations, the effect of various factors on the dependent variable was analysed while controlling two factors, such as treatment duration and dose. An analysis of covariance (ANCOVA) was also performed, which permitted the assessment of how a given factor influences the dependent variable while controlling for the effects of covariates. Statistical significance was considered at $\mathrm{p}$ values $\leq 0.05$.

\section{Results}

\section{The effect of mecasermin treatment on the body height of patients}

The whole group showed an improvement in body height expressed as SDS in relation to sex and age. The mean body height SDS was $-3.52 \pm 0.82$ before treatment, and $-2.25 \pm 0.91$ after 36 months of treatment $(\mathrm{p}<0.01)$. The average increase in height was 


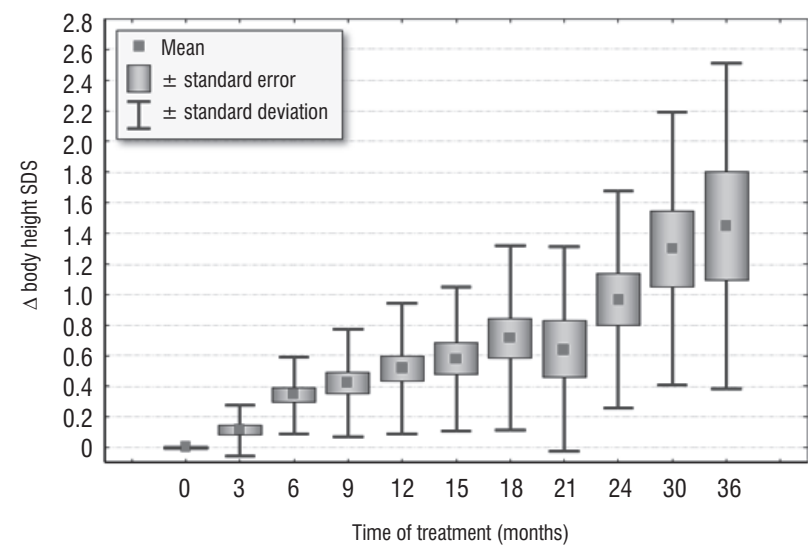

Figure 2. Change of body height SDS during treatment Rycina 2. Zmiana wartości SDS wysokości ciała podczas terapii

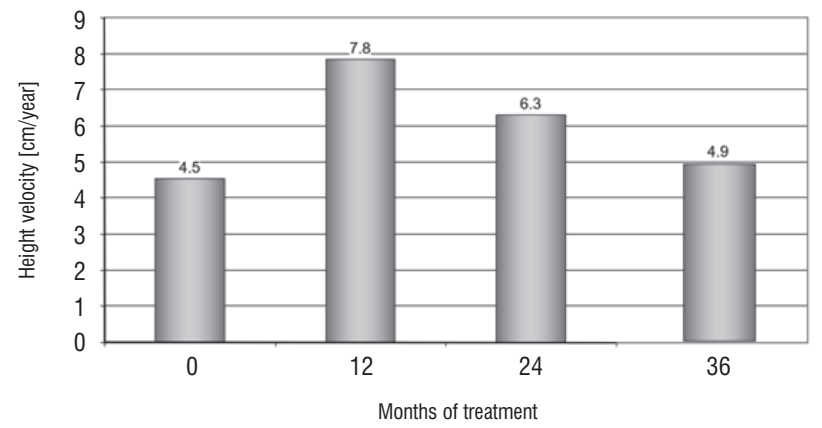

Figure 3. Height velocity during treatment

Rycina 3. Tempo wzrastania podczas terapii

$1.45 \pm 1.06$ SD. (Fig. 2). The apparent decrease in mean body height SDS change observed in the $21^{\text {st }}$ month of therapy may be a result of not every site providing the results in this particular time point of the study. It has to be noted that while strictly controlled by the rules of a state-funded therapeutic program, the study was not a clinical trial, there was thus some area for freedom in setting the control timepoints in any given study site.

There was also an improvement in the height velocity. Starting at an average of $4.5 \pm 1.6 \mathrm{~cm} /$ year, the greatest improvement occurred in the first year of treatment, when the average value was $7.8 \pm 1.9$ $\mathrm{cm} /$ year. In the second year of treatment, the average height velocity was $6.3 \pm 0.8 \mathrm{~cm} /$ year, whereas in the third year of treatment the mean height velocity was $4.9 \pm 1.8 \mathrm{~cm} /$ year (Fig. 3).

\section{The effect of mecasermin treatment on the body weight of patients}

There was a statistically significant relationship between the treatment time and the body weight of patients, expressed as SDS in relation to sex and age. During three years of treatment the body weight SDS increased from

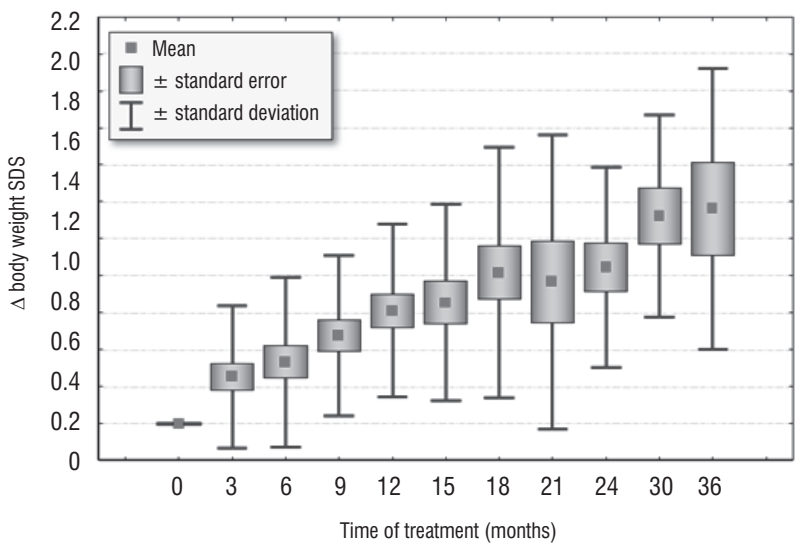

Figure 4. Change of body weight SDS during treatment Rycina 4. Zmiana wartości SDS masy ciała podczas terapii

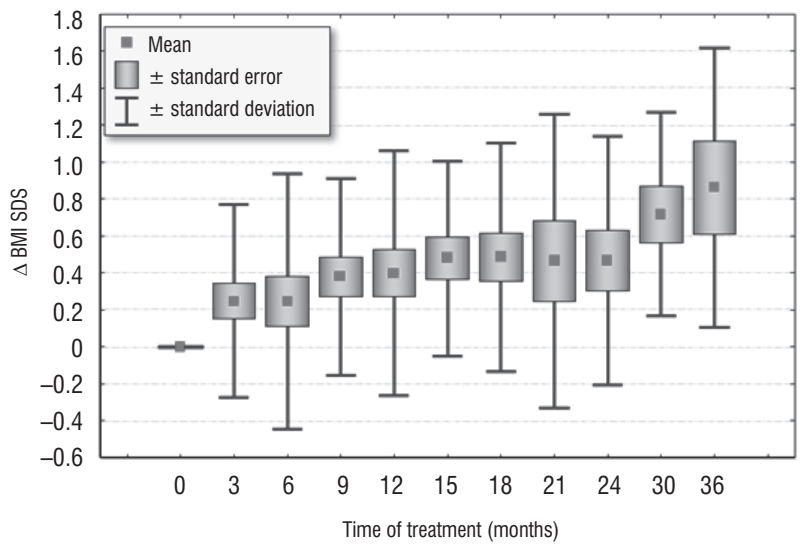

Figure 5. Change of BMI SDS during treatment

Rycina 5. Zmiana wartości BMI SDS podczas terapii

$-3.14 \pm 1.14$ to $-1.95 \pm 0.99(\mathrm{p}<0.01)$. The mean weight gain in the whole group was $1.16 \pm 0.76 \mathrm{SD}$ (Fig. 4).

The body mass index (BMI) of the treated children also changed significantly. During three years of treatment the BMI SDS for sex and age increased from $-1.79 \pm 1.30$ to $-0.91 \pm 0.99(\mathrm{p}<0.01)$. The average increase in BMI was $0.86 \pm 0.75 \mathrm{SD}$ ( $\mathrm{p}<0.01)$ (Fig. 5).

The relationship between the change in height and body weight during treatment with respect to the pre-treatment concentration of GH and IGF-1 in treated children was tested.

The statistical analysis also examined the effect of certain factors, such as maximum GH concentration and baseline IGF-1, on the dependent variable when controlling two other factors, one of which was always the treatment duration, while the second one was mecasermin dose.

Both the partial correlation coefficients and the pvalues were obtained while controlling the treatment time and the medication dose. 


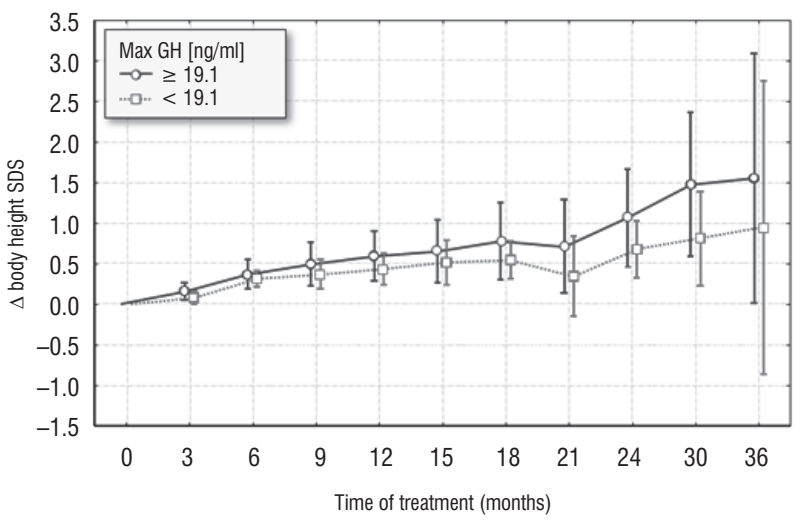

Figure 6. Change of body height SDS during treatment, depending on pre-treatment GH peak. Diagram of means and confidence interval (95\%)

Rycina 6. Zmiana wartości SDS wysokości ciata podczas terapii $w$ zależności od wydzielania GH przed leczeniem

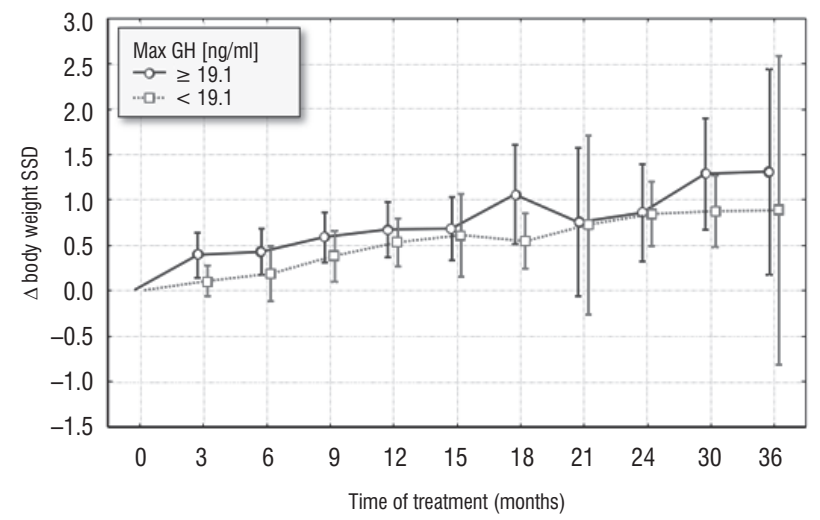

Figure 7. Change of body weight SDS during treatment, depending on pre-treatment GH peak. Diagram of means and confidence interval (95\%)

Rycina 7. Zmiana wartości SDS masy ciała podczas terapii w zależności od wydzielania GH przed leczeniem

The correlation between peak GH concentration and change in body height was significant $(r=0.93$, $\mathrm{p}<0.01$ ), as well as the correlation between peak GH concentration and change in body height SDS $(r=0.76$, $p<0.01$ ). The correlation between peak GH concentration and an increase of body weight was also significant $(\mathrm{r}=0.76, \mathrm{p}<0.01)$, similarly to the change in body weight SDS $(\mathrm{r}=0.41, \mathrm{p}<0.01)$.

The correlation between baseline IGF-1 concentration and change in body height was not significant $(\mathrm{r}=0.93, \mathrm{p}=0.81)$. The correlation between baseline IGF-1 SDS and increase of body height SDS was also not significant $(\mathrm{r}=0.48, \mathrm{p}=0.58)$. Interestingly, the correlation between baseline IGF-1 and body weight increase during three years of treatment occured only

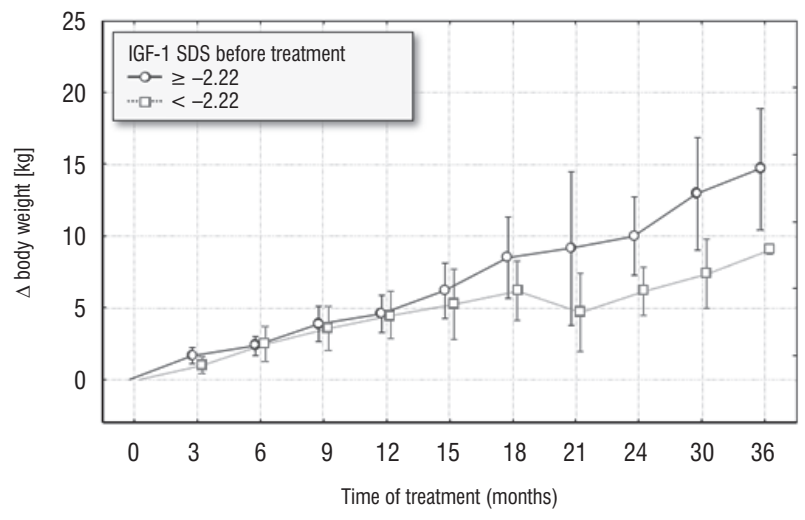

Figure 8. Change of body weight during treatment, depending on IGF-1 SDS before treatment. Diagram of means and confidence interval (95\%)

Rycina 8. Zmiana masy ciała podczas terapii w zależności od wartości IGF-1 SDS przed leczeniem

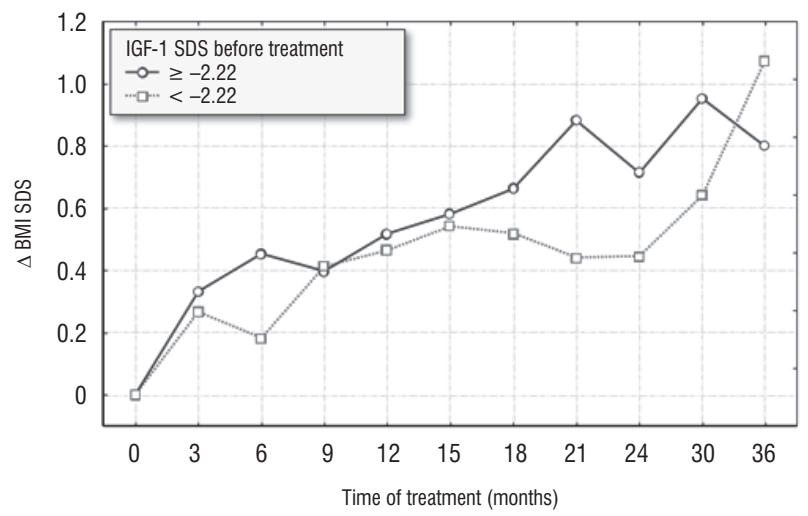

Figure 9. Change of BMI SDS during treatment, depending on IGF-1 SDS before treatment. Diagram of means

Rycina 9. Zmiana BMI SDS podczas terapii w zależności od wartości IGF-1 SDS przed leczeniem

in the case of body weight expressed in kilograms $(\mathrm{r}=0.78, \mathrm{p} \leq 0.01)$; for body weight expressed as SDS for age and sex, the p-value was 0.86 .

In patients with initially higher levels of GH $(\geq 19.1 \mathrm{ng} / \mathrm{ml})$, increases in height and body weight were greater than in patients with lower $\mathrm{GH}(<19.1 \mathrm{ng} / \mathrm{ml})$. The difference was statistically significant $(\mathrm{p}<0.01)$ (Fig. 6 and 7).

A similar relationship occurred between the change in body weight and BMI, and the initial concentration of IGF-1 expressed as SDS for sex and age. Patients with more severe IGF-1 deficiency $(<-2.22 \mathrm{SD})$ increased their body weight and BMI less than children with initially higher IGF-1 concentrations $(\geq-2.22 \mathrm{SD}$ ) (Fig. 8 and 9). The difference was statistically significant $(\mathrm{p}<0.01)$. 


\section{Side effects}

Treatment side effects were reported in eight patients $(29.63 \%)$.

Two patients $(7.41 \%)$ experienced hypoglycaemia during the sixth month of treatment. In one of them, this was associated with a deterioration of appetite and a reduction in the number of meals taken. A blood glucose level of $56 \mathrm{mg} / \mathrm{dl}$ was observed once. After returning to the previous diet, no further episodes of hypoglycaemia were noted. The second patient was treated with a maximal dose of $120 \mu \mathrm{g} / \mathrm{kg}$ bw twice a day. During the sixth month of treatment, a blood glucose level of $40 \mathrm{mg} / \mathrm{dl}$ was observed once. No dose adjustment was required, and no further hypoglycaemia episodes were noted.

Two patients $(7.41 \%)$ had hyperlipodystrophy changes in the sites of injections. One patient (3.7\%) developed hypertrophy of the lymphatic tissue of the pharyngeal tonsils; the same patient also had an increase in scoliosis diagnosed before. One patient (3.7\%) reported headaches during treatment. Another patient (3.7\%) reported hair loss as an adverse event during the treatment. The connection between the event and the therapy is, however, unclear.

Three patients finished their treatment in the course of the study.

Two patients terminated treatment early due to side effects. One of the patients showed thickening of the ventricular septum in echocardiographic examination. The treatment was discontinued between the fifth and seventh month of treatment, for the duration of the cardiac diagnosis. The patient was scheduled for heart valve implantation surgery. Eventually, treatment was discontinued after 30 months of therapy. The other patient suffered from conductive hearing loss due to chronic exudative otitis media. In addition, the patient remained under orthopaedic care because of left-sided scoliosis in the Th6-12 section of the spine. Due to the progression of the curve from 18 degrees in 2009 to 41 degrees in 2011, the treatment was discontinued in the second year of therapy.

One of the patients ended her treatment after three years, having reached a bone age indicating the end of therapy (14 years). The patient's initial body height expressed as SDS for sex and age was $-4.00 \mathrm{SD}$, and her final height after treatment was $-3.05 \mathrm{SD}$, which means a change in body height of +0.95 SD.

\section{Discussion}

The aim of the study was to present the results of treatment with rhIGF-1 of the first patients in the Polish population.

When comparing the treatment benefits with the occurrence of side effects, attention should be paid to the differences in the qualification for treatment with mecasermin in the United States and in European Union countries. The most important of these is the concentration of IGF-1 expressed as SDS in relation to age and sex. In the US, short-statured children with body height SDS $\leq-3.0$ and IGF-1 SDS $\leq-3.0$ are qualified for the treatment. Patients with GH gene deletion in which growth hormone-neutralising antibodies have been generated are also eligible for treatment. In Europe, the use of IGF-1 is recommended for the long-term treatment of children with severe primary IGF-1 deficiency, referred to as body height SDS $\leq-3.0$, with a baseline IGF-1 below percentile 2.5 for sex and age. The European definition describes in more detail the level of growth hormone and excludes secondary forms of IGF-1 deficiency [5, 6]. Also, in the population of Polish patients, there were no children with the classic phenotype of Laron syndrome. Additionally, two of the patients qualified for treatment did not fully meet the criteria for inclusion in the therapeutic program in Poland.

This can be explained by the more liberal approach of the qualifying team in the initial period of the therapeutic program, which could have resulted from a small group of treated patients. The study sums up the first Polish experience with IGF-1 deficiency treatment, with all the patients taking part in the study being the first patients ever to be qualified for the treatment in Poland.

When discussing the qualification of children for rhIGF-1 treatment, one should refer to the controversy caused by the somatomedin generation test. Although most paediatric endocrinologists surveyed in Europe carried out this test in recent years, and in $45 \%$ of cases the result was necessary to start treatment, its predictive value is low (sensitivity $77-91 \%$, specificity $\leq 97 \%$ ). According to some authors, due to the limitations of the test in the diagnosis of the most severe IGF-1 deficiencies resulting from $\mathrm{GH}$ insensitivity syndrome, its usefulness for the diagnosis of milder cases is questionable [7]. Another problem is the lack of a unified testing methodology in different centres. This was not an issue with the Polish group, due to unified recommendations regarding the test method. The researchers did not have, however, control over the laboratory method for IGF-1 determination. The patients' blood samples were not assessed in one central laboratory, but instead they were tested in the individual centres where treatment was conducted, which could lead to discrepancies in the assessment and interpretation of the results obtained.

It is also worth noting that the median value of maximal GH concentrations (measured during spontaneous nocturnal secretion or after pharmacological stimulation) of $19.1 \mathrm{ng} / \mathrm{ml}$ suggests GH-insensitivity in this group of patients. 
In every study evaluating the long-term effects of rhIGF-1 treatment, a significant increase in the height velocity was observed in the first year of treatment with a slowdown in subsequent years $[5,8,9]$. A clear beneficial effect of rhIGF-1 therapy on the height of the treated patients was found, but most of them will not reach a final height within the population standard. The height velocity in the described group of Polish patients (approximately $8 \mathrm{~cm} /$ year in the first year of treatment) is similar to that in the groups described by other authors $[5,8,9]$.

When assessing the results of treatment in terms of body height, the impact of patient compliance cannot be neglected. The lack of dedicated pens for the drug and the need to perform two injections per day significantly reduced compliance for therapy over time in some patients, as was demonstrated by the amount of drug returned at control visits. During the treatment, only the endocrine form of IGF-1 is supplemented, which may affect the final effects of treatment by disturbing paracrine and autocrine secretion. It has been proven that the results of treatment are not affected by the lack of exogenously administered IGFBP-3 and ALS. A single daily dose of rhIGF-1/rhIGFBP-3 is effective in maintaining the physiological concentration of IGF-1 in the absence of ALS. RhIGF-1 injections twice a day provide similar effects despite deficiency of both ALS and IGFBP-3, the concentration of which is not corrected by IGF-1 treatment [1].

The literature describes many potential side effects of treatment. The most common of these are hypoglycaemia, headache, and lipohypertrophy at the site of drug administration.

The increased risk of hypoglycaemia results from the similarity between the rhIGF-1 and insulin molecules. The literature, however, indicates effective prevention of glycaemic decline through proper nutrition and administration of the drug with a meal $[10,11]$. The incidence of at least one hypoglycaemic episode has been described in $14 \%$ [12] to as many as $49 \%$ [9] of patients, including $10 \%$ of episodes of severe hypoglycaemia accompanied by seizures in $6 \%$ of cases. However, in the study of Chernausek et al. [9], 32\% of children reporting hypoglycaemia experienced episodes of hypoglycaemia before starting the treatment. The higher numbers of episodes of hypoglycaemia in the aforementioned studies (especially Chernausek et al.) can be explained by patients presenting classic Laron syndrome phenotype, which was present in those groups. There were no such cases among the Polish patients.

In the Polish group of patients, hypoglycaemia occurred in $7.41 \%$ of patients; it was mild, transient, and did not require treatment modification.
Hypertrophy of the lymphatic tissue in patients treated with rhIGF-1 may be associated with sensorineural hearing loss, snoring, and sleep apnoea syndrome due to hypertrophy of the palatine tonsils and the pharyngeal tonsil. In some patients this entails the need for adenotomy and/or tonsillectomy. Due to the incidence of ear, nose, and throat complications in previous studies, an audiometric test was included in the standard evaluation protocol during treatment with rhIGF-1. In the study by Chernausek et al. [9], 22\% of patients had laryngological complications, and surgical intervention was necessary in $11 \%$. In the Polish group, one patient $(3.7 \%)$ presented hypertrophy of the lymphatic tissue of the pharyngeal tonsils. It is possible that this percentage was underestimated in both studies, due to the time needed to develop such side effects.

Chernausek et al. [9] described lipohypertrophy at the injection site as a common (32\%) local complication of treatment with rhIGF-1. It can be prevented, as with insulin, by changing the injection site during the next administration. In the Polish group, the problem was found in two patients $(7.41 \%)$.

Other side effects described in the literature $[5,9$, 12] are much less common, and include orthopaedic problems, increased intracranial pressure, and kidney stones. Of those possible side effects, one of the patients presented an increase in the curve of scoliosis. One of the patients in the Polish group experienced hair loss, an adverse reaction not reported previously in the literature. Due to the lack of other reports on this subject, and the numerous reports on the beneficial effects of IGF-1 preparations on hair growth resulting from its anti-apoptotic action [13], coincidence of the symptom with rhIGF1 therapy cannot be ruled out.

\section{Summary and conclusions}

Until recently, rhGH was the only treatment option available for children with severe short stature. Currently, rhIGF-1 is an additional therapeutic option. It has been proven safe and effective in increasing the height velocity and in improving the final height in a very limited number of patients who have been confirmed to have primary IGF-1 deficiency.

The published data show that rhIGF-1 therapy in patients with primary IGF-1 deficiency significantly accelerates the height velocity in the first year of treatment. The velocity falls in subsequent years of treatment, but not to the level measured before therapy. Growth response to rhIGF-1 is not as strongly expressed, nor is it maintained for as long as the response to $\mathrm{GH}$ in children with GH deficiency. Treatment has been shown to be effective, resulting in benefits in the form of increasing the patients' body height SDS. 
The therapy was safe. Except for two patients, side effects in the group of Polish patients were rare, mild, transient, and did not require treatment modifications.

\section{References}

1. Rosenbloom AL. Mecasermin (recombinant human insulin-like growth factor I). Adv Ther. 2009; 26(1): 40-54, doi: 10.1007/s12325-008-0136-5, indexed in Pubmed: 19198769.

2. Filus A, Zdrojewicz Z. Insulinopodobny czynnik wzrostu-1 (IGF-1) - budowa i rola w organizmie człowieka [Insulin-like growth factor-1 (IGF-1) - structure and the role in the human body. Pediatr Endocrino Diabetes Metab. 2015; 20(4): 161-169, doi: 10.18544/PEDM-20.04.0016, indexed in Pubmed: 26615583.

3. Iranpoor H, Omidinia E, Vatankhah V. Expression of Recombinant Human Insulin-like Growth Factor Type 1 (rhIGF-1) in Escherichia coli. Avicenna J Med Biotechnol. 2015; 7(3): 101-105, indexed in Pubmed: 26306149.

4. Petriczko E, Wikiera B, Horodnicka-Józwa A, et al. A two year observation of the process of applying recombinant IGF-1 to treat short stature in children with primary IGF-1 deficiency - case reports of 3 patients. Pediatr Endocrinol Diabetes Metab. 2011; 17(4): 233-238 indexed in Pubmed: 22248785.

5. Backeljauw P, Bang P, Clayton PE. Diagnosis and management of primary insulin-like growth factor-I deficiency: current perspectives and clinical update. Pediatr Endocrinol Rev. 2010; 7 Suppl 1: 154-171, indexed in Pubmed: 20463651.

6. Hardin DS. Statement 6: patients who are unresponsive to GH therapy should be given a trial of IGF-I. Pediatr Endocrinol Rev. 2008; 5(Supp 3): 857-860, indexed in Pubmed: 18438330.
7. Coutant R, Dörr HG, Gleeson H. Diagnosis of endocrine disease: limitations of the IGF1 generation test in children with short stature. Eur Endocrinol. 2012; 166(3): 351-357, doi: 10.1530/EJE-11-0618, indexed in Pubmed: 22048966

8. Ranke MB, Savage MO, Chatelain PG. Long-term treatment of growth hormone insensitivity syndrome with IGF-I. Results of the European Multicentre Study. The Working Group on Growth Hormone Insensitivity Syndromes. Horm Res. 1999; 51(3): 128-134, doi: 10.1159/000023345, indexed in Pubmed: 10461018.

9. Chernausek SD, Backeljauw PF, Frane J. Long-term treatment with recombinant insulin-like growth factor (IGF)-I in children with severe IGF-I deficiency due to growth hormone insensitivity. J Clin Endocrinol Metab. 2007; 92(3): 902-910, doi: 10.1210/jc.2006-1610, indexed in Pubmed: 17192294.

10. Guevara-Aguirre J, Rosenbloom AL, Vasconez O. Two-year treatment of growth hormone $(\mathrm{GH})$ receptor deficiency with recombinant insulin-like growth factor I in 22 children: comparison of two dosage levels and to GH-treated GH deficiency. J Clin Endocrinol Metab. 1997; 82(2): 629-633, doi: 10.1210/jcem.82.2.3743, indexed in Pubmed: 9024266.

11. Richmond EJ, Rogol AD. Recombinant human insulin-like growth factorI therapy for children with growth disorders. Adv Ther. 2008; 25(12): 1276-1287, doi: 10.1007/s12325-008-0124-9, indexed in Pubmed: 19066756.

12. Midyett LK, Rogol AD, Van Meter QL, et al. MS301 Study Group. Recombinant insulin-like growth factor (IGF)-I treatment in short children with low IGF-I levels: first-year results from a randomized clinical trial. J Clin Endocrinol Metab. 2010; 95(2): 611-619, doi: 10.1210/jc.2009-0570, indexed in Pubmed: 19880790

13. Ahn SY, Pi LQ, Hwang ST, et al. Effect of IGF-I on Hair Growth Is Related to the Anti-Apoptotic Effect of IGF-I and Up-Regulation of PDGF-A and PDGF-B. Ann Dermatol. 2012; 24(1): 26-31, doi: 10.5021/ad.2012.24.1.26, indexed in Pubmed: 22363152 